\title{
Seasonal distribution, abundance, habitat use and population identity of humpback whales in Oman
}

\author{
G. Minton*,+, T. Collins*,^, K. Findlay ${ }^{\#}$, P. Ersts $\sim$, H. Rosenbaum**, P. Berggren ${ }^{++}$And R. Baldwin ${ }^{*}$ \\ Contacte-mail: gianna.minton@gmail.com
}

\begin{abstract}
Previously published data on the occurrence of humpback whales (Megaptera novaeangliae) in the Arabian Sea suggests that the region hosts a non-migratory population that adheres to a Northern Hemisphere breeding cycle. In order to investigate the distribution and abundance of this population, twelve small boat surveys were conducted in three main locations off the coast of Oman between February 2000 and November 2004. Humpback whales were observed during surveys in Dhofar and Gulf of Masirah on Oman's Arabian Sea coast, but not during surveys in the Muscat region in the Gulf of Oman. An even ratio of males to females was observed and sampled during surveys in the Gulf of Masirah, which was surveyed in October and November $(n=38)$, while almost all whales sampled in Dhofar in February/March were male $(n=28)$. Song was detected frequently in the bay surrounding the Halaniyat Islands (formerly known as the Kuria Muria Bay) in February/March, but observations of mother-calf pairs were sparse, and competitive groups were absent. Feeding was observed in both October/November and February/March, but behavioural and environmental observations indicate that the Gulf of Masirah is primarily an important feeding ground, while the Dhofar region, particularly the Halaniyat Bay, may be a breeding area. However, limited survey effort and a lack of recent observations of mother-calf pairs or competitive groups raises the possibility that the primary mating, calving and nursing areas are yet to be identified. Sixty-four individual whales were identified using photographs of dorsal fins or tail flukes. A high rate of re-sightings between years and between survey areas at different times of the year indicates year-round residence off the coast of Oman. A Chapman's modified Petersen estimator was applied to various data pairings to calculate abundance. All pairings yielded estimates of less than 100 individuals, but sample sizes were small and there were various sources of possible bias. Analysis of scarring on the caudal peduncle region of identified individuals in Oman indicates that between 30 and $40 \%$ are likely to have been involved in entanglements with fishing gear. Comparison of the Oman photo-identification catalogue with those from Zanzibar, Antongil Bay (Madagascar) and Mayotte and the Geyser Atoll (Comoros Archipelago), yielded no photographic matches. These data are consistent with the hypothesis of a discrete population. The distribution of fluke pigmentation rankings from the Oman catalogue, which varied significantly from those of Madagascar and Mayotte, provides further evidence for this theory. The evidence presented here provides a strong underpinning for the recent IUCN Red List classification of the Arabian Sea sub-population of humpback whales as Endangered. In light of ongoing coastal development and other threats to this population's habitat and future survival, urgent research and conservation measures are recommended.
\end{abstract}

KEYWORDS: HUMPBACK WHALE; ARABIAN SEA; OMAN; MARK-RECAPTURE; BREEDING GROUNDS; FEEDING GROUNDS; DISTRIBUTION; ENTANGLEMENT; PHOTO-ID; GENETICS; NORTHERN HEMISPHERE

\section{INTRODUCTION}

Humpback whales (Megaptera novaeangliae) are known to undertake seasonal migrations between high latitude summer feeding grounds and tropical winter breeding grounds (e.g. Chittleborough, 1965; Clapham and Mead, 1999; Dawbin, 1966). Feeding and breeding cycles in Northern and Southern Hemisphere populations are typically six months out of phase (Lockyer, 1984). Although some circumstantial evidence exists for limited interbreeding between hemispheres, particularly off the South American coast of the central Pacific Ocean, (Acevedo-Gutiérrez and Smultea, 1995; Caballero et al., 2001; Flórez-González et al., 1998; Hazevoet and Wenzel, 2000; Stone et al., 1990), genetic evidence supports traditional stock definitions originally described from distributions observed by whaling fleets and marking data (Breiwick, 1983). These stocks or subpopulations typically demonstrate high fidelity to well defined breeding areas and seasons, and little mixing occurs between populations (Baker et al., 1998; Baker and Medrano-González, 2001; Baker et al., 1990; MedranoGonzalez et al., 2001).
Early records of humpback whales from the Arabian Sea region in the Northern Hemisphere include whaling data and observations collected from merchant vessels (Brown, 1957; Slijper et al., 1964; Wray and Martin, 1983). No feasible migration routes can link this population to the high latitude Northern Hemisphere regions, and most observers suggested these animals belonged to Southern Hemisphere stocks (e.g. Brown, 1957). However, these authors were unable to account for sightings made in the Arabian Sea during the austral summer. Reeves et al. (1991) presented a thorough review of historical and incidental records of humpback whales in the Northern Indian Ocean, and explored the hypothesis that some humpback whales may be resident (Whitehead, 1985; Winn et al., 1981). Evidence arising from the catch of 238 humpback whales illegally taken off Oman and Pakistan in November and December 1966 suggests that Arabian Sea whales represent a separate stock, adhering to a Northern Hemisphere breeding cycle (Mikhalev, 1997; 2000).

High primary productivity associated with strong monsoon-driven upwelling in the Arabian Sea may create conditions suitable for feeding at latitudes more typically

\footnotetext{
* Environment Society of Oman, PO Box 3955, PC 112, Ruwi, Sultanate of Oman.

+ Sarawak Dolphin Project, Universiti of Malaysia Sarawak, Kota Samarahan 94300, Sarawak, Malaysia Wildlife Conservation Society Ocean Giants Program, 2300 Southern Blvd, Bronx, NY 10460-1099, USA.

* Oceanography Department, University of Cape Town, Rondebosch 7701, South Africa.

Center for Biodiversity and Conservation, American Museum of Natural History, Central Park West at 79th Street, New York, NY 10024, USA.

** Wildlife Conservation Society, Ocean Giants Program, 2300 Southern Blvd., Bronx, NY 10460-1099, USA.

${ }^{++}$School of Marine Science and Technology, Newcastle University, Newcastle upon Tyne, NE1 7RU, UK.
} 
associated with breeding (Baldwin, 2000; Mikhalev, 1997; Papastavrou and Van Waerebeek, 1997; Reeves et al., 1991). Mikhalev (2000) found that over 50\% of humpback whales caught and examined in the Arabian Sea $(n=190)$ had full stomachs, indicating that feeding occurred during the Austral summer, when Southern Hemisphere populations should be feeding in the Southern Ocean. In addition, biological data on reproductive females and calf lengths indicated a reproductive cycle in line with Northern Hemisphere populations (Mikhalev, 2000).

Although data collected prior to 2000 confirmed a population of humpback whales in the Arabian Sea, information on seasonal distribution, habitat use, population identity, abundance and status were limited. This paper reviews all available confirmed records of humpback whales in Oman including results of a series of small boat surveys and one shore-based survey carried out off the coast of Oman between February 2000 and October 2003. This review aims to investigate the seasonal distribution, habitat use, abundance and conservation status of humpback whales in Oman.

\section{METHODS}

\section{Study areas and field survey methods}

Small-boat surveys were conducted over a period of four and a half years in three main locations: the Gulf of Masirah; the Dhofar region (both on the Arabian Sea coast); and off Muscat in the Gulf of Oman (Fig. 1). Surveys were designed to target areas where published (Mikhalev, 2000) and unpublished records indicated potential humpback whale abundance, and the timing and location of surveys is detailed in Table 1. Survey timing was to some extent constrained by funding opportunities, personnel availability and logistic constraints, while rough seas and fog generated by the SW Monsoon limited effort along the Arabian Sea coast during the summer months (May-September). As a result, the Gulf of Masirah was typically surveyed during October and November, and the Dhofar region during February and March. Additionally, single-day surveys were conducted on an average of once a month in the Muscat region throughout the study period. While all available survey and photoidentification data from the 2000-03 surveys were used in the analyses below, the data from the 2004 Gulf of Masirah survey in this paper are limited to photo-identification data for use in mark-recapture analysis.

Tracks were designed to optimise coverage of nearshore and offshore (beyond the $200 \mathrm{~m}$ isobath up to roughly $3,000 \mathrm{~m}$ ) waters within the determined survey region. However logistical considerations (range of the vessel, fuel supplies, safe anchorages, weather conditions, etc.) often limited the length and range of search tracks. Search speeds ranged from 12 to 15 knots.

The majority of surveys were conducted from a $6.5 \mathrm{~m}$ rigid-hulled inflatable boat (RIB), powered by two outboard engines ( 70 or $85 \mathrm{hp}$ ). Effort was logged to the minute, and all sightings were recorded using standardised data collection methods (e.g. Mattila et al., 1994). Although the survey collected data on all species of cetacean encountered, priority was given to humpback whales. Types of data collected during each humpback whale sighting included (in order of priority) positional data, group composition, behaviour, photographic (tail flukes, right and left dorsal fins), skin samples and acoustic recordings.

Weather conditions were recorded on an hourly basis and search effort was suspended in Beaufort Sea states of 4 or higher. A minimum of two experienced observers positioned on the bow, on a $3 \mathrm{~m}$ high A-frame, or on the deck of the boat scanned assigned arcs with the naked eye, in order to collectively cover 180 degrees forward of the beam. Surveys were conducted in closing mode, and search effort was suspended to approach and collect data on all cetaceans sighted. In January and February 2000, two observers conducted opportunistic searches from vessels involved in a multidisciplinary expedition off the Halaniyat Islands, while the survey conducted from 15-17 October 2000 used a $5.5 \mathrm{~m}$ fibreglass fishing skiff powered by a $25 \mathrm{hp}$ engine to survey the northern portion of the Gulf of Masirah.

In an effort to address the paucity of sightings data from monsoon months and confirm or refute the presence of humpback whales during the Northern Hemisphere summer months, a four-day shore-based survey was conducted from cliff-tops near Duqm (in the southern portion of the Gulf of Masirah) in June 2001. Four observers worked in rotation with two observers searching the sea simultaneously, one with binoculars and one with the naked eye, for two-hour shifts. Sightings were recorded, but no data on movement or individual identification are available from this survey.

\section{Tissue sampling and sex determination}

Sloughed skin was collected opportunistically with a sieve from dive wells or following breaches (Amos et al., 1992). From October 2001, biopsies were taken with a crossbow and hollow-tipped, barbed biopsy darts (Lambertsen et al., 1994). Tissue samples were stored in salt saturated water with $20 \%$ dimethyl sulfoxide (DMSO) (Amos and Hoelzel, 1991) for genetic analysis.

\section{Group composition and behaviour}

Group types and behavioural classifications were based on a consensus of categories used in other studies (e.g. Baker and Herman, 1984; Brown and Corkeron, 1995; Clapham, 1993; Clapham et al., 1992; Mattila et al., 1989; Mattila et al., 1994).

\section{Acoustic watches}

Acoustic watches were conducted from February 2001 onward with the primary aim of detecting humpback whale song. Search effort was suspended and a hydrophone (Offshore Acoustics, Vancouver) was deployed to a depth of $5-10 \mathrm{~m}$ for a period of 15 minutes. Detected song was assigned to one of three perceived levels of intensity as a crude measure of the distance of the whale from the hydrophone: ' 1 ' being distant, '2' medium and ' 3 ' close range. Recordings were made using a Sony TCD-D100 digital audiotape (DAT) recorder. Efforts were then made to locate, photograph and biopsy the singing whale if it had not already been detected visually prior to the acoustic watch.

\section{Photo-identification and matching}

Every effort was made to photograph the ventral surface of the tail flukes (Katona and Whitehead, 1981) and the left and right sides of the dorsal fin of each humpback whale encountered. A variety of cameras was used, including both $35 \mathrm{~mm}$ film and digital SLR cameras fitted with $70-300 \mathrm{~mm}$ or $130-400 \mathrm{~mm}$ zoom lenses.

\section{Data analysis}

\section{Sighting classifications}

All sighting data were entered into the Oman Cetacean Database (OMCD), an MS Access database, and were then classified into four effort categories. 

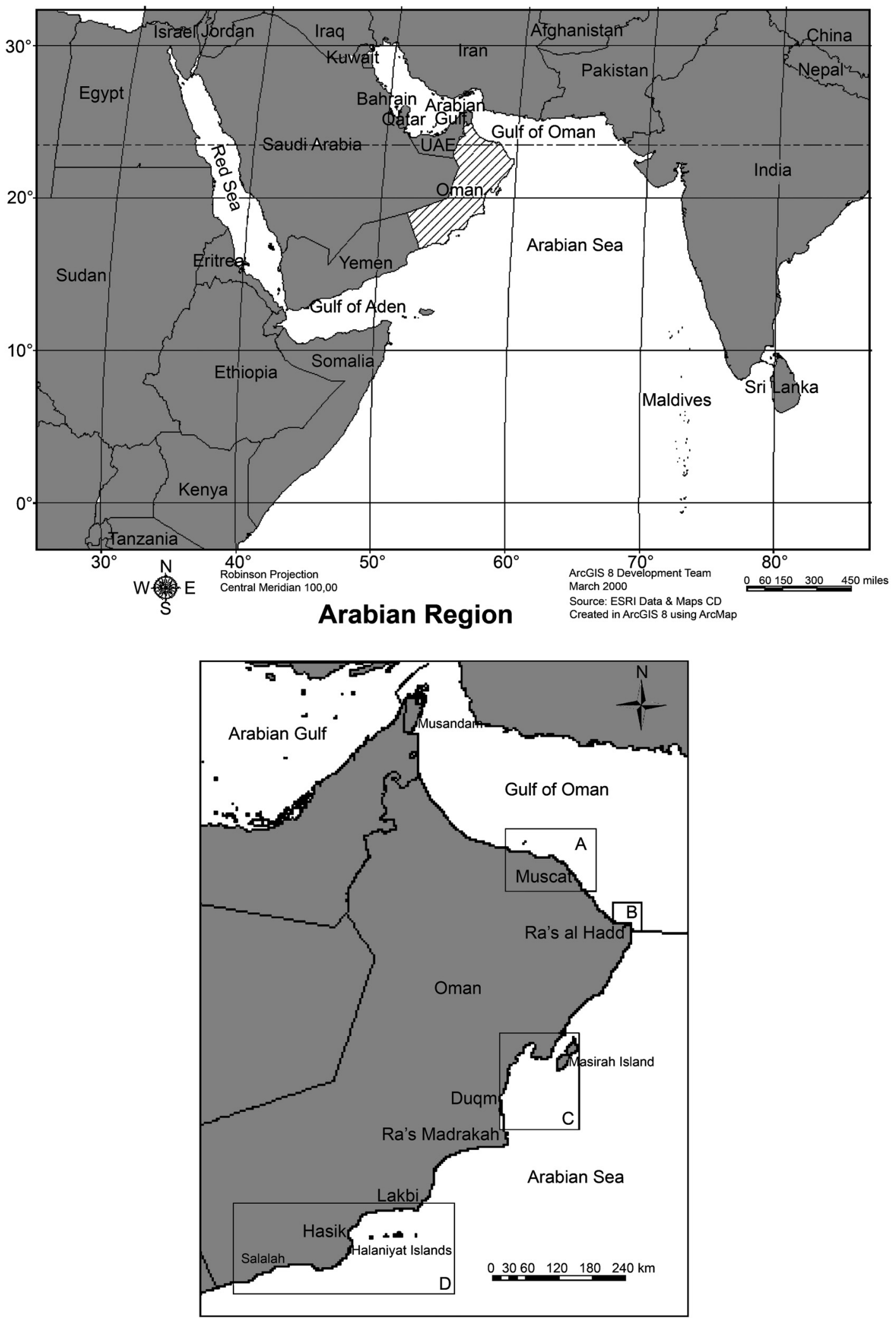

Fig. 1. Four main study areas in Oman. A: Muscat region, linear distance covered from 2001-2003 =2,264km. B: R'as al Hadd $($ one survey only) $=200.8 \mathrm{~km}$. C: Gulf of Masirah $=2,555.24 \mathrm{~km}$. D: Dhofar region $=3,819.71 \mathrm{~km}$.

(a) Type $1(n=56)$ : recorded during optimal survey effort (minimum of 2 observers, $12-15 \mathrm{kt}$ search speed).

(b) Type $2(n=3)$ : recorded during sub-optimal survey effort (higher vessel speeds or fewer observers).

(c) Type 3: recorded while 'off effort' during surveys $(n=$ $13)$, during acoustic watches $(n=6)$ or by authors outside of survey times with no associated effort $(n=7)$. Shore- based observations $(n=13)$ and seismic survey records $(n=47)$ are also included here (Baldwin, 1997). These have been treated as incidental sightings made by authors and no associated effort has been analysed.

(d) Type $4(n=25)$ : Incidental or dedicated sighting records from reliable third parties (including Ballance and Pitman, 1998; Mikhalev, 1997; Reeves et al., 1991; Salm 
Table 1

Dates and locations of surveys and encounter rates for humpback whales sighted on effort during surveys.

\begin{tabular}{|c|c|c|c|c|c|c|}
\hline Survey area & Survey dates & Effort hours ${ }^{1}$ & $\begin{array}{c}\text { Number of level } 1 \\
\text { sightings }\end{array}$ & $\begin{array}{l}\text { Number of } \\
\text { whales }\end{array}$ & $\begin{array}{l}\text { Sightings } \\
\text { per hour }\end{array}$ & $\begin{array}{c}\text { Number of } \\
\text { whales per hour }\end{array}$ \\
\hline Muscat $^{2}$ & $15 / 03 / 01-15 / 07 / 03$ & 104.21 & 0 & 0 & 0.00 & 0.00 \\
\hline \multicolumn{7}{|l|}{ Dhofar } \\
\hline Halaniyat Islands & $15-24 / 01 / 00$ and $08-21 / 02 / 00$ & 63.50 & 9 & 18 & 0.14 & 0.28 \\
\hline Dhofar & $09-22 / 02 / 01$ & 34.26 & 5 & 9 & 0.15 & 0.26 \\
\hline Halianiyat Bay & $16-22 / 02 / 01$ & 16.01 & 6 & 8 & 0.375 & 0.5 \\
\hline Dhofar & $10 / 02 / 02-02 / 03 / 02$ & 62.37 & 9 & 12 & 0.14 & 0.19 \\
\hline Halaniyat Bay & $17 / 02 / 02-01 / 03 / 02$ & 34.8 & 11 & 15 & 0.36 & 0.431 \\
\hline Hasik Bay & $24-26 / 0602$ & 4.32 & 0 & 0 & 0.00 & 0.00 \\
\hline Lakbe and Halaniyats & $17-20 / 11 / 02$ & 36.83 & 2 & 3 & 0.05 & 0.08 \\
\hline Dhofar & 24/02/03-19/03/03 & 116.31 & 7 & 8 & 0.06 & 0.07 \\
\hline Halaniyat Bay & $01-12 / 03 / 03$ & 97.20 & 7 & 8 & 0.07 & 0.08 \\
\hline Dhofar (Hasik only) & $15-17 / 0503$ & 2.17 & 1 & 1 & 0.46 & 0.46 \\
\hline Dhofar $^{3}$ & $04-29 / 03 / 04$ & & & & & \\
\hline Dhofar total & & 319.76 & 33 & 51 & 0.10 & 0.16 \\
\hline \multicolumn{7}{|l|}{ Gulf of Masirah } \\
\hline N. Gulf of Masirah & $15-17 / 10 / 00$ & 11.00 & 4 & 6 & 0.36 & 0.55 \\
\hline Gulf of Masirah & $04-27 / 10 / 01$ & 83.15 & 8 & 11 & 0.10 & 0.13 \\
\hline Gulf of Masirah & 24/10/02-17/11/02 & 58.20 & 11 & 17 & 0.19 & 0.29 \\
\hline Gulf of Masirah ${ }^{3}$ & 04-29/11/04 & & & & & \\
\hline Masirah total & & 152.35 & 23 & 34 & 0.15 & 0.22 \\
\hline \multicolumn{7}{|l|}{ Shore-based observations } \\
\hline Duqm & $10-13 / 06 / 01$ & 25.00 & 5 & 7 & 0.20 & 0.28 \\
\hline
\end{tabular}

${ }^{1}$ Effort indicates time spent actively searching for whales and excludes time spent working with whales, in transit, or on breaks. ${ }^{2}$ Monthly surveys. ${ }^{3}$ Only photo-id data from these surveys are used in the analyses presented here for use in capture-recapture estimates.

et al., 1993), observations by M.D. Gallagher (19701998) and reports supported with photographs or video footage.

Only Type 1 sightings are used in analysis of relative abundance and encounter rates. However, Type 2-4 sightings are used to varying degrees in analysis of group composition, behaviour and seasonal distribution.

\section{Sex determination}

Both sloughed skin $(n=12)$ and biopsy samples $(n=44)$ were used for determination of sex, which was accomplished by PCR amplification and subsequent Taq I digestion of homologous regions on the $\mathrm{X}$ and $\mathrm{Y}$ chromosomes (ZFX/ZFY) (Palsbøll et al., 1992). Sloughed skin was only definitively assigned to an individual if it was a singleton. Adult whales accompanied by a calf were considered females and singletons confirmed to be singing were considered male.

Photo-identification, matching and population estimates Photographs (from $35 \mathrm{~mm}$ print or slide film) were filtered for quality and the best representative photos of each feature (left dorsal, right dorsal or tail flukes) of each individual whale at each encounter were selected, scanned at high resolution (600 dpi), and cropped to best frame the identifying feature (dorsal fin or tail flukes). Raw digital images were labelled, filtered for quality and enhanced. The selected images were then linked to a database containing sighting history information.

All selected images were scored using one general quality ranking that included consideration of sharpness, contrast, angle and proportion of the identifying feature visible in the image. Scores ranged from 1 to 4 .

(1) Poor quality: 'unmatchable' under any circumstances, but with utility as a reference.

(2) Fair quality: shows only a portion of the identifying feature (i.e. one half of the flukes), is out of focus, or compromised by glare. These images could be used to recognise distinctive individuals.

(3) Good quality: in focus and shows all of the identifying features.

(4) Excellent quality: shows all aspects of the identifying feature in great detail.

Scoring was based on photo quality and orientation only and was independent of the distinctiveness of individuals as described by Friday et al. (2000).

Photo-identification data were used to: (1) compute estimates of abundance with capture-recapture methods; (2) investigate seasonal variation in movements; and (3) investigate the stock identity of whales from Oman by comparison with other populations in the Indian Ocean.

Matching was completed by comparing digital images on a computer screen and suspected matches were verified independently. All catalogue images were matched regardless of quality ranking but only those of quality 3 or higher were used in capture-recapture analysis. All but one of the individuals included in the sample were considered to be adults, with a low probability of changes occurring to their natural markings over time (Blackmer et al., 2000; Carlson et al., 1990). Matches made from poor quality images were included in the analysis of individual sighting histories and seasonal movements.

The Chapman's-modified Petersen two sample estimator was used to compute capture recapture abundance estimates (Chapman, 1951) as illustrated in Seber (1982, p.60) with 95\% log-normal confidence intervals. Three data pairings were chosen, all requiring some compromise between maximal sample size and minimisation of potential sources of bias.

(1) Individuals photographed in the Gulf of Masirah in October 2001 as the first sample $\left(n_{1}\right)$ and individuals photographed in the Gulf of Masirah in OctoberNovember 2002 as the second sample $\left(n_{2}\right)$.

(2) All individuals photographed in either the Gulf of Masirah or Dhofar between October 2000 and November 
Table 2

Details of the total number of individuals and breakdown of photo quality for each feature of individuals held in the photoID catalogues for Oman, Zanzibar, Mayotte/Geyser (Comoros Archipelago) and Antongil Bay, Madagascar. LDF = left dorsal fin, $\mathrm{RDF}=$ right dorsal fin, $\mathrm{TF}=$ tail fluke. Photo quality rankings for all three catalogues followed the same criteria as adapted from Friday et al. (2000).

\begin{tabular}{lccrrrrr}
\hline Research area & $\begin{array}{c}\text { Total number } \\
\text { of individuals }\end{array}$ & LDF' $>1^{\prime}$ & LDF $>2$ & RDF $>1$ & RDF'>2 & TF $>1$ & TF $>2$ \\
\hline Oman & 54 & 38 & 24 & 40 & 24 & 43 & 32 \\
Zanzibar & 7 & 5 & 3 & 1 & 1 & 2 & 2 \\
Mayotte/Geyser & 185 & 104 & 39 & 101 & 42 & 44 & 26 \\
Antongil Bay, Madagascar & 1,104 & 736 & 380 & 753 & 382 & 601 & 357 \\
\hline
\end{tabular}

2002 as the first sample $\left(n_{1}\right)$ and all individuals photographed either the Gulf of Masirah or Dhofar between between March 2003 and November 2004 as the second sample $\left(n_{2}\right)$.

(3) All individuals photographed in the Gulf of Masirah between October 2000 and November 2004 as the first sample $\left(n_{1}\right)$ and all individuals photographed in Dhofar between January 2000 and March 2004 as the second sample $\left(n_{2}\right)$.

Fifty-four individual whales photographed in Oman between 1999 and November May 2003 were matched against seven individuals photographed off Zanzibar in September 2002, 1,104 individuals from Antongil Bay, Madagascar (1996 through 2002), and 185 individuals from Mayotte/Geyser Reef, Comoros Archipelago (1999-2002) (see Table 2). The matching process included all available photos of tail flukes and dorsal fins, regardless of quality.

Photo quality ranking and fluke pigment assignations for the four compared populations were conducted by different researchers in each study area. However, clear definitions of quality scores and fluke types, shared across all catalogues, as well as authors' ability to review catalogues from different populations, should have kept any discrepancies to a minimum.

Individuals from all four regions for which tail fluke photographs of quality 3 or higher existed were assigned to pigmentation categories between 1 and 5, with 1 representing an all white fluke, and 5 representing an all black fluke (Carlson et al., 1990). Comparison of frequencies of pigmentation categories between populations was conducted using the non-parametric $\chi^{2}$ statistics. Sexing data was not available for the whales from the Zanzibar, Madagascar and Mayotte/Geyser catalogues at the time of this analysis, so comparisons were not stratified by sex.

Analyses of humpback whale caudal peduncle scars Photographs of the peduncle region (right and left flanks, the leading edge of the flukes, dorsal and ventral aspects of the peduncle) were isolated and examined for evidence of scarring consistent with entanglement or encounters with fishing gear following Robbins and Mattila (2000). Caudal peduncle images were scored for quality on the same scale as that for individual identification. The selected photographs were then scored for the type of scarring present (scar code), and the 'probability of entanglement' status indicated by these scars (entanglement code) following Robbins and Mattila (2000).

\section{RESULTS}

Table 1 details the effort spent on each survey in each survey area between 2000 and 2004. On effort portions of surveys covered a total of $8,839 \mathrm{~km}$ with search effort distributed somewhat unevenly between survey areas as follows:
$2,264 \mathrm{~km}$ in Muscat; $200.8 \mathrm{~km}$ in Ras al Hadd; $2,555.24 \mathrm{~km}$ in the Gulf of Masirah; and 3,819.71 km in the Dhofar region (see also Fig. 2).

\section{Seasonal distribution and relative abundance}

Encounter rates of humpback whales per effort-hour (Table 1) varied between surveys, with some surveys (e.g. all Muscat surveys) yielding no on-effort humpback whale sightings, and other surveys yielding encounter rates as high as 0.55 whales per hour. However, the differences in encounter rates were not statistically significant $\left(\chi^{2}=1.49\right.$, df $11, p=1.00)$.

Relative abundance and depth and slope associations of humpback whales and other cetaceans encountered during surveys is discussed in greater detail elsewhere (Minton et al., 2010; Corkeron et al., 2011). Fig. 2 depicts humpback whale encounter rates per kilometre searched in each $0.1 \times$ 0.1 decimal degree grid square (approximately $11 \times 11 \mathrm{~km}$ ). Fig. 3 depicts all type 1-4 humpback whale sightings grouped by season.

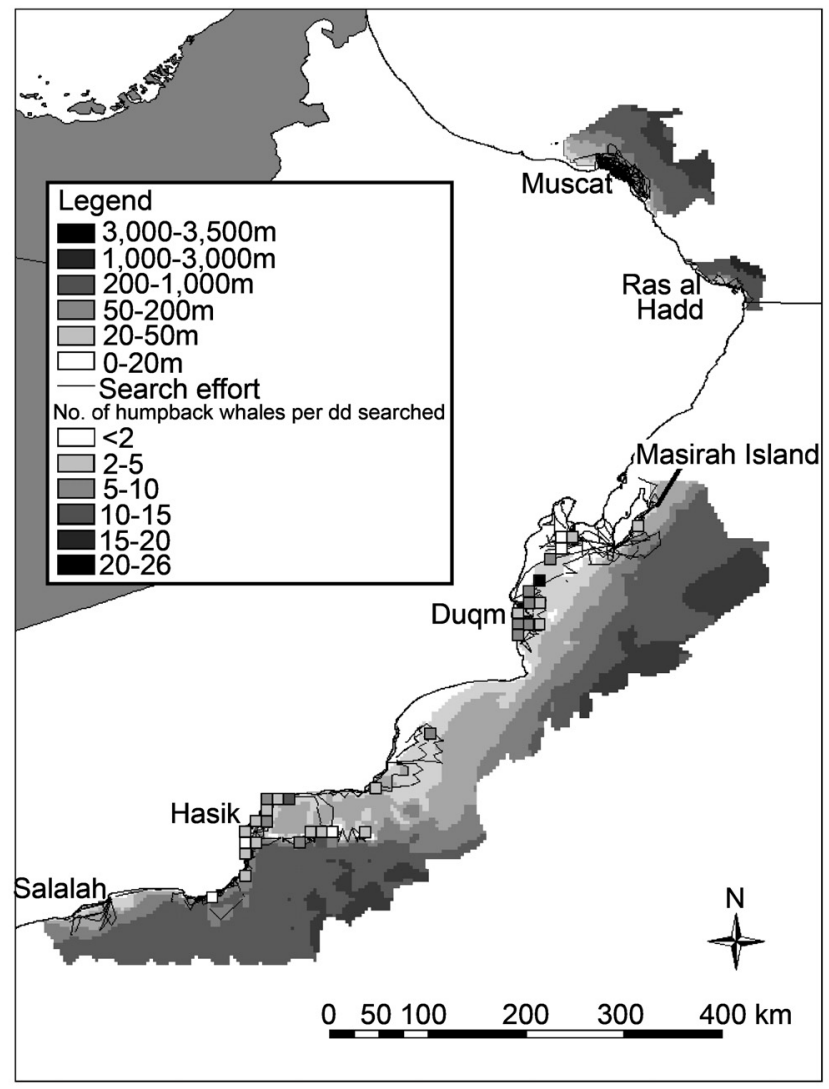

Fig. 2. Humpback whale encounter rates per kilometer searched in each 0.1 $\times 0.1$ Decimal Degree grid square (approximately $11 \mathrm{~km} \times 11 \mathrm{~km}$ ). Darker shading indicates higher encounter rates relative to the distance searched. 


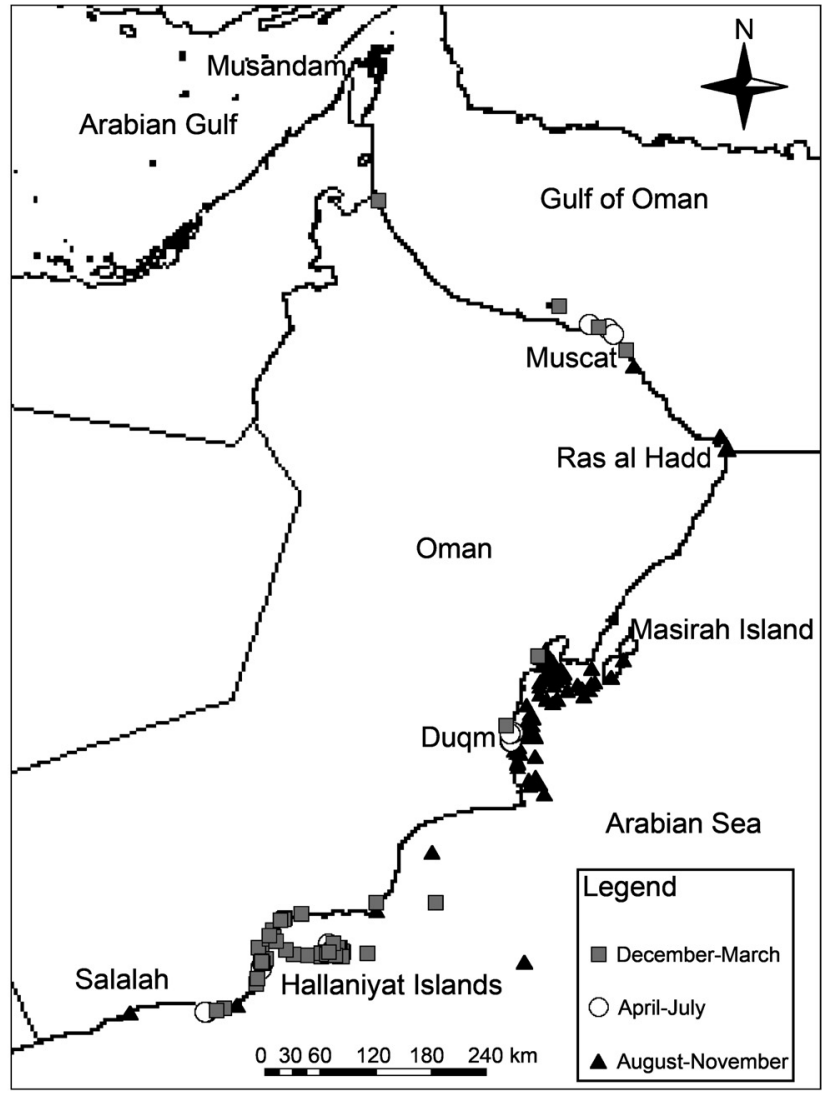

Fig. 3. Distribution of type 1-4 humpback whale sightings by season.

The sighting history of four whales (all males) photoidentified off Oman suggests that movements are seasonal (Fig. 4). With the exception of one single sighting (whale OM00-003, Fig. 4), all individuals were seen in the Dhofar region in February and in the Gulf of Masirah in October. While six of the males identified in Dhofar were also observed in the Gulf of Masirah, only one of the 19 known females observed in the Gulf of Masirah was also observed in Dhofar. Three additional females were re-sighted between years in the Gulf of Masirah.

\section{Habitat use}

The size and composition of groups sighted across surveys and regions is shown in Fig. 5. Type 1-3 sightings are included here because the sample size of Type 1 sightings is low $(n=56)$, and determination of group composition is not influenced by whether the groups were encountered on-effort.

Fifty percent of animals observed across surveys were singletons. G-tests using the observed group compositions from sightings in the Gulf of Masirah as the expected range and group compositions observed in Dhofar as the actual range show significant differences in the distribution of group composition categories between the two regions $(p<0.01)$. In Dhofar $62 \%(n=36)$ of all sightings were singletons, of which $33 \%(n=12)$ were confirmed singers. Pairs were the second most frequent group composition, comprising between $32 \%$ and $35 \%$ of all sightings. Trios were rare, occurring only in the Gulf of Masirah. Quartets and competitive groups were entirely absent across all surveys.

Sex was determined (either through genetic sampling, singing, or presence of calf) for 38 of 44 individually identified whales observed between October 2000 and November 2002 in the Gulf of Masirah and for 28 of 37 individually identified whales observed between 2000 and
2003 in Dhofar. Pairs or trios of whales in Masirah were more often of mixed sex, while in Dhofar, those pairs for which the sex of both individuals could be determined were most often male (Table 3 ).

Fig. 6 summarises the dominant behaviour categories observed during Type 1-3 encounters across surveys and per region. Behavioural categories were based on the most prominent behaviour of the groups encountered, excluding any behaviours that were judged to have been caused by interaction with the research vessel.

G-tests using the observed behaviours in the Gulf of Masirah as the expected range and behaviours observed in Dhofar as the actual range show significant differences in the distribution of behaviour categories between the two regions $(p<0.01)$. Singing was detected only in February and March in Dhofar, where it was the dominant behaviour $(39 \%, n=44)$. Confirmed instances of feeding at the surface span both the October/November and February/March observation periods, but were more common in the Gulf of Masirah in October/November. Singing was only detected in the Dhofar region (Table 4, Fig. 7).

\section{Abundance}

Table 5 depicts the results of the application of Chapman's modified Petersen model to three different pairings of data sets. All of the data pairings yield population estimates of less than 100 individuals with fairly narrow confidence intervals.

\section{Stock identity}

The comparison of the Oman catalogue with those from Zanzibar, Madagascar and Mayotte yielded no matches. Furthermore, there appeared to be notable differences in visible scaring and certain morphological characteristics between the populations. The Madagascar and Mayotte whales displayed a higher degree of barnacle scarring on the tail flukes, a higher rate of killer whale scarring, and a difference in the frequency of certain characteristic dorsal fin shapes (e.g. hooked dorsal fins are relatively common in Madagascar, but very rare in Oman).

Table 6 depicts the distribution of fluke pigmentation classes for the individuals sampled in the three different study areas. Sexing data was not available for the catalogues outside of Oman and is not presented here.

$\chi^{2}$ tests detected significant differences between populations in the distribution of fluke pigmentation types. Two separate expected ranges were generated for Oman by multiplying the Antongil Bay ratios of fluke pigmentation by the total number of flukes in Oman (32), and then doing the same for Mayotte/Geyser. Observed frequencies in Oman varied significantly with respect to both Antongil Bay $\left(\chi^{2}=15.15 \mathrm{df}=4, p=0.003\right)$ and Mayotte/Geyser $\left(\chi^{2}=14.77\right.$ $\mathrm{df}=4, p=0.003)$.

\section{Entanglement histories and scarring}

Twenty-three individual whales were included in the analysis of caudal peduncle photographs with a quality score of 2 (poor to fair) or higher. Of these $31 \%(n=7)$ showed no scarring or scarring that was not characteristic of entanglement. In total, $70 \%$ of the animals had varying degrees of scarring on the peduncle region that could have been caused by encounters with fishing gear (linear wrapping scars or notches characteristic of net or rope lesions). However, only $39 \%(n=9)$ were judged to have overall scarring patterns conclusive enough to be considered indicative of previous entanglement. 

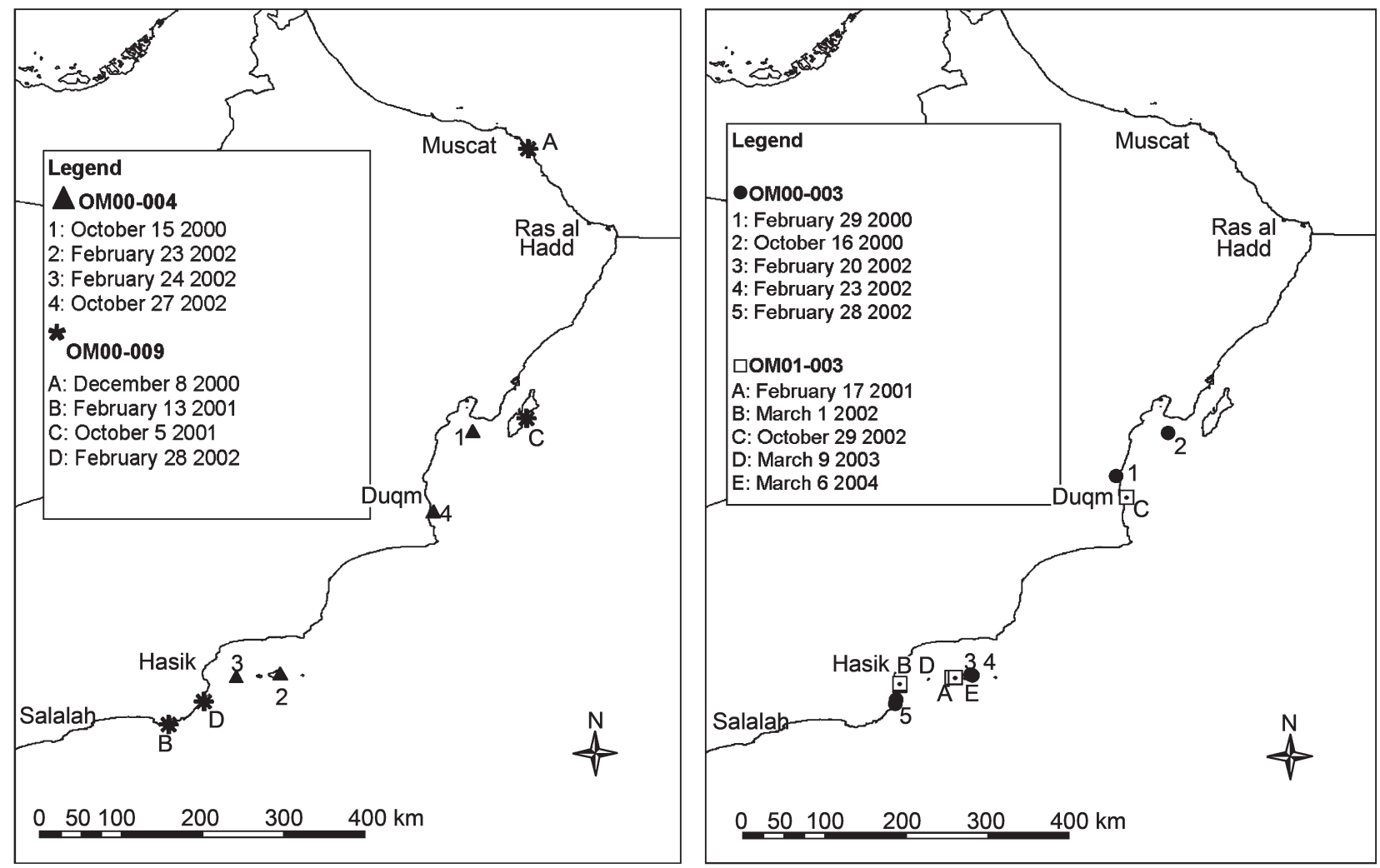

Fig. 4. Sighting histories and locations of 4 of the most frequently sighted individual humpback whales.

The same analysis was performed on a smaller sub-group of individuals who were assigned caudal peduncle photographic quality scores of 3 or higher. This sub-group comprised only 12 individuals. For this group, $42 \%$ of the animals $(n=5)$ showed random scarring that was not consistent with entanglement, while $58 \%(n=7)$ had at least some scarring that could have been caused by entanglement. Of this smaller sub-group, $33 \%(n=4)$ were considered to have overall scarring patterns likely to have been caused by previous entanglement.

\section{DISCUSSION}

Seasonal distribution, movements and relative abundance The high proportion of re-sightings of previously photographed individuals across surveys provides some

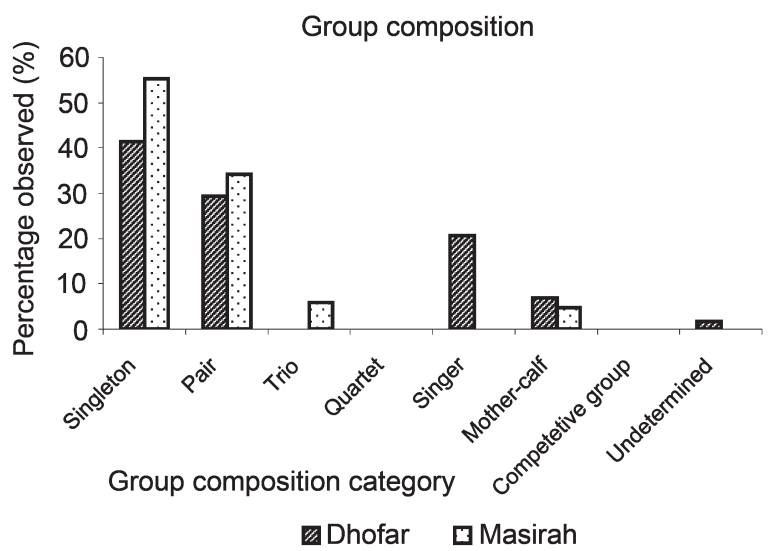

Fig. 5. Percentage breakdown of group composition categories assigned during type 1-3 humpback whale sightings made in the Gulf of Masirah $(n=85)$ and Dhofar $(n=58)$ regions. indication that the surveys targeted areas used regularly by at least some individuals within the Arabian Sea population. They provide a strong indication that a number of individual whales remain in Omani waters year-round, and that they frequent both the Gulf of Masirah and Dhofar. The relatively short duration of surveys, and the fact that surveys were designed to cover different portions of the survey areas on different days did not facilitate accurate analysis of occupancy rates, and may explain the relatively low rate of within survey re-sights $(n=8)$.

Type 3 and 4 sightings (Fig. 4) and unpublished records in the OMCD suggest that there may be areas of seasonal abundance off the coast of Oman that have not yet been covered by our surveys. There is also a possibility that some whales rove the Arabian Sea on a seasonal basis or in response to shifts in productivity, utilising areas off the west coasts of Iran, Pakistan, India and Sri Lanka or the Gulf of Aden. Although a number of sources refer to sightings and

Table 3

Composition of groups in which individuals of known sex occurred.

\begin{tabular}{lcccc}
\hline & Male & Female & Mixed & Unknown \\
\hline Gulf of Masirah & & & & \\
Singleton & 8 & 8 & N/A & \\
Pair & 0 & 0 & 2 & $3^{1}$ \\
Trio & 0 & & 3 & $1^{2}$ \\
Dhofar & & 0 & N/A & \\
Singleton & 14 & 0 & 0 & $4^{3}$ \\
Pair & 5 & 0 & 0 & 0 \\
Trio & 0 & & & \\
\hline
\end{tabular}

${ }^{1} 2$ pairs contained one male and one unknown, one pair contained a mother and calf of unknown sex; ${ }^{2}$ one trio contained two females and one individual of unknown sex; ${ }^{3} 2$ pairs contained one male and one unknown individual, one pair contained one female and one individual of unknown sex. 


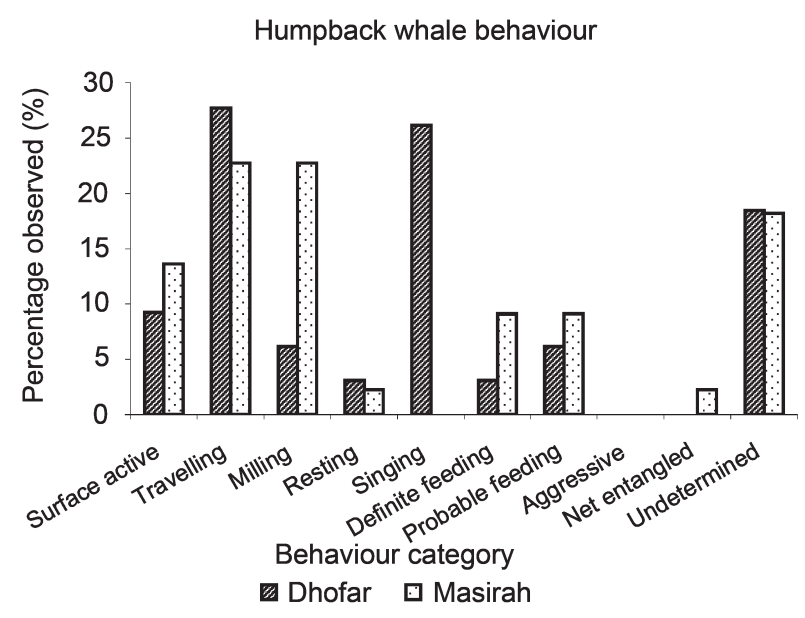

Fig. 6. Behaviour categories assigned (\%) during type 1-3 sightings in the Gulf of Masirah $(n=44)$ and Dhofar $(n=65)$.

strandings of the species in this region (e.g. Ahmed and Rizvi, 1985; de Silva, 1987; Lal Mohan, 1992; Mathew, 1948; Mikhalev, 1997; Reeves et al., 1991; Sathasivam, 2000; Slijper et al., 1964; Whitehead, 1985), only a handful of dedicated cetacean surveys have been conducted anywhere in the Arabian Sea since the 1960s, and the majority (Alling et al., 1982; Ballance and Pitman, 1998; Eyre, 1995) have focused effort in more offshore waters and have included no observations of humpback whales.

\section{Habitat use}

The high incidence of singers and detected song in the Kuria Muria Bay in February and March suggests that the area is used as a breeding ground (Payne and McVay, 1971; Tyack, 1981 ) and is consistent with a January-April breeding season predicted by Mikhalev $(1997 ; 2000)$. The higher ratio of males to females observed in Dhofar is also similar to ratios reported from other breeding areas in the Southern Hemisphere, such as Antongil Bay, Madagascar (2.2-2.4:1), and Gabon (1.9-2.1:1) (Pomilla and Rosenbaum, 2006; Rosenbaum et al., 2009).

Conversely, the conspicuous absence of competitive groups is inconsistent with observed abundances on
Caribbean (Mattila et al., 1989; Mattila et al., 1994) or Hawaiian (Baker and Herman, 1984) breeding grounds. In Oman, observed group size never exceeded three individuals. On three occasions, interactions between pairs of adult males included surface active behaviour and fast swimming, but at no point were any of these activities conspicuously agonistic. This included a brief penis extrusion, a behaviour thought to be associated with male dominance contests (Pack et al., 2002). A similar lack of competitive interactions is reported for humpback whales observed in New Caledonia (Garrigue et al., 2001) and in other breeding grounds of the South Pacific where humpback whale densities are low (C.S. Baker, pers. comm.). Alternatively, competitive groups may be formed in areas not surveyed in this study.

The total lack of observations of mother-calf pairs since 2001 also contrasts with the high incidence of singing detected in February and March. The percentage of groups containing mother-calf pairs $(7 \%)$ observed in the Dhofar region in February is much lower than on other breeding grounds, such as Samana Bay (Dominican Republic) where $15 \%$ of all sightings contained a calf (Mattila et al., 1994), Antongil Bay, Madagascar, where $12 \%$ of groups observed were mother-calf pairs (Ersts and Rosenbaum, 2003; Rosenbaum et al., 2002b), Mozambique, where 14\% of all size-confirmed groups $(n=237)$ in September 2003 contained a calf (Findlay et al., 2011), Mayotte and Geyser Atoll (Comoros Archipelago) where over $70 \%$ of sightings included mother-calf pairs (Ersts and Rosenbaum, 2002) and in Zanzibar in September 2002 where three of the five groups identified were mother-calf pairs. Following the lack of observations of mother-calf pairs in 2001 and 2002, the 2003 Dhofar survey was shifted to the first two weeks of March, as previous surveys might have been too early to cover peak calving periods. However, the 2003 survey yielded a lower encounter rate for humpback whales in general, with no calf sightings.

As with the competitive groups, it is possible that calving and nursing are taking place predominantly in areas (either in Oman or elsewhere) that were not covered in our surveys. One suspected nursery area is the Gulf of Masirah. Craig et al. (2003) and Smultea (1994) suggest that availability of protected, shallow waters may be the key variable limiting distribution of mother-calf pairs on breeding grounds. The Gulf of Masirah contains a much greater area of shallow,

Table 4

Surveys during which regular acoustic watches were held, number of acoustic watches held on each survey, and frequency with which song was detected on each survey.

\begin{tabular}{|c|c|c|c|c|}
\hline Survey area & Survey dates & $\begin{array}{c}\text { Number of } \\
\text { acoustic watches }\end{array}$ & $\begin{array}{c}\text { Number of } \\
\text { incidences of song }\end{array}$ & $\begin{array}{c}\% \text { of acoustic } \\
\text { watches with song }\end{array}$ \\
\hline Muscat (monthly surveys) & $15 / 03 / 01-15 / 07 / 03$ & 25 & 0 & 0 \\
\hline \multicolumn{5}{|l|}{ Dhofar } \\
\hline Dhofar & $09-22 / 02 / 01$ & 12 & 4 & 33 \\
\hline Dhofar & $10 / 02 / 02-02 / 03 / 02$ & 65 & 44 & 68 \\
\hline Hasik Bay & $24-26 / 06 / 02$ & 9 & 0 & 0 \\
\hline Halaniyat Bay & $17-20 / 11 / 02$ & 6 & 0 & 0 \\
\hline Dhofar & $24 / 02 / 03-19 / 03 / 03$ & 63 & 28 & 44 \\
\hline Dhofar (Hasik only) & $15-17 / 05 / 03$ & 1 & 0 & 0 \\
\hline Dhofar total & & 156 & 76 & 49 \\
\hline \multicolumn{5}{|l|}{ Gulf of Masirah } \\
\hline Gulf of Masirah & $04-27 / 10 / 01$ & 6 & 0 & 0 \\
\hline Gulf of Masirah & $24 / 10 / 02-20 / 11 / 02$ & 16 & 0 & 0 \\
\hline Masirah total & & 22 & 0 & 0 \\
\hline \multicolumn{5}{|l|}{ Other areas } \\
\hline Ra's al Hadd & $30 / 03 / 01-02 / 04 / 01$ & 4 & 0 & 0 \\
\hline
\end{tabular}




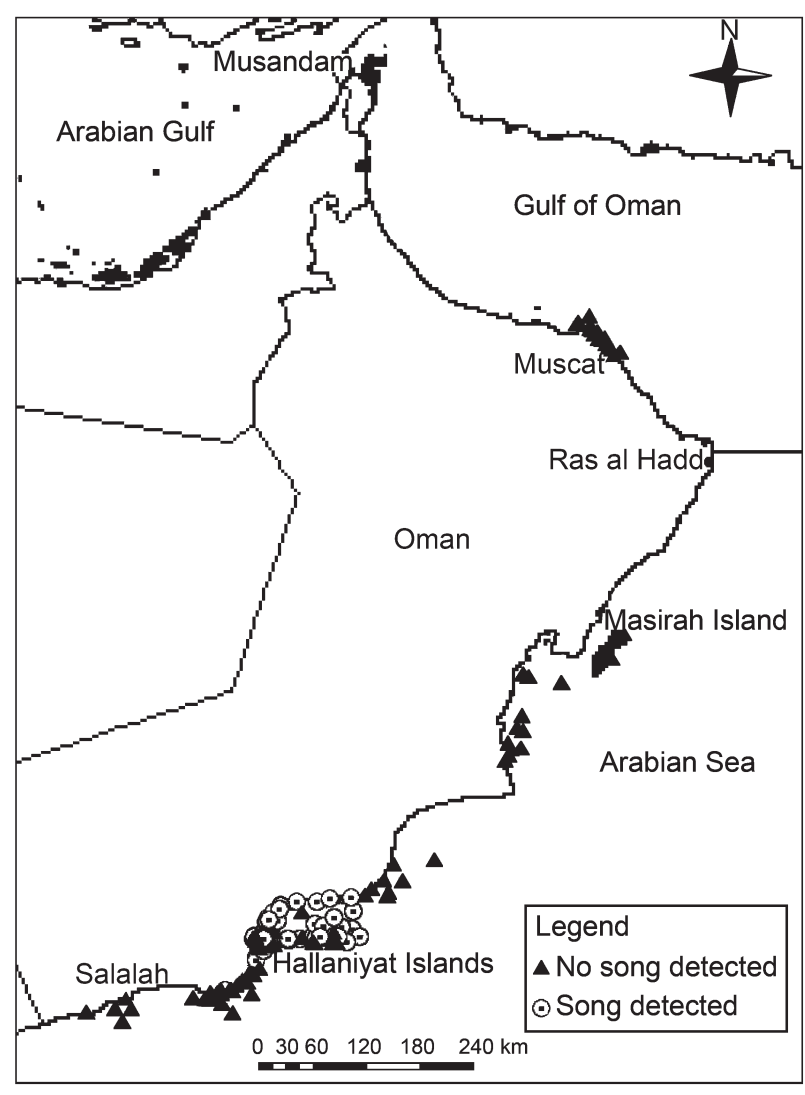

Fig. 7. Sites of acoustic watches throughout all survey areas in Oman (a), with triangles indicating no song detected and circles indicating detection of song. All song was detected during February and March surveys in the Dhofar region.

protected habitat than the Dhofar region (Fig 3). This area is also consistently characterised by high productivity (Brock and McClain, 1992; Brock et al., 1998; Marine Science and Fisheries Center Oman, 2001). If productivity is linked to feeding opportunities for nursing females, it would seem reasonable to assume its attractiveness as a nursing area. One mother-calf pair (calf-size indicating several months old) was observed here in October 2001, but weather conditions and other logistic constraints have prevented the authors from surveying this area later in the breeding season (e.g. February-March), when more calves might be expected.

It seems inconsistent that cow-calf groups were observed around the Halaniyat Islands in February 2000, but not during equivalent periods in subsequent years. Mikhalev (2000) also noted a paucity of mother calf pairs in the Arabian Sea humpback whale population. Although $45 \%$ of the females examined in the Soviet catch were pregnant, only $3 \%$ of them were lactating, and only one mother-calf pair was observed during the hunt. Northern Hemisphere calves at this time of year could be approaching separation (Lockyer, 1981), but experienced observers would recognise these individuals as calves, as they are considerably smaller in length than the adults around them (7-9 m vs. 11-14m) (Clapham, 2000; Clapham et al., 1999a). The Soviet catch data do not provide more explicit details of catches by region, so it is impossible to determine whether pregnant females were found in the Eastern Arabian Sea as opposed to the coasts of Oman.

The gender ratio in the Soviet catch neared parity (126:112), so the paucity of mother-calf pairs in recent observations cannot be explained by a bias in the Soviet catch toward females. There is a possibility that due to low population densities (Leaper et al., 2006) or other fitness related factors, such as those affecting the North Atlantic right whale (IWC, 2001), birth rates are extremely low in the Arabian Sea population. Alternatively, birth rates may be resource dependent. Cerchio (2003) noted a pronounced decrease in reproduction of humpback whales in the Revelligigedo Islands in 1998, and a spike in reproduction in 2000 (as measured by percentage of mother-calf pairs observed), hypothesising that the dip was related to reduced prey availability during the El Niño event of 1997/98. The finding by Leaper et al. (2006) of a time-delayed relationship between sea surface temperature (SST) anomalies and southern right whale reproductive success lends further credibility to this theory. Brock and McClain (1992) reported that a weak 1982 southwest monsoon coincided with a $72 \%$ reduction in pigment concentration. This degree of variation could have significant impacts on prey availability for humpback whales. Visual inspection of remotely sensed chlorophyll-a data obtained for our survey periods indicated a high level of annual variation in Chlorphyll-a concentrations, but this could not be quantitatively analysed with respect to humpback whale distribution due to small sighting sample sizes in relation to the time-scale of the Chlorophyll-a data.

Feeding was observed in both Dhofar and the Gulf of Masirah. However observations of whales lunging at the surface with open mouths and/or extended throat pleats were rare, even in areas of conspicuously high productivity. This is surprising, particularly in light of Mikhalev's (1997) report that over $50 \%$ of humpback whales taken had full or halffull stomachs. It is probable that several instances of subsurface feeding went undetected (e.g. Clapham, 1993).

Remotely sensed chlorophyll-a imagery shows consistently high levels of surface chlorophyll-a in the Gulf of Masirah (Brock and McClain, 1992; Brock et al., 1998), while more recent studies detected a higher biomass of zooplankton in this region than any other of any part of Oman's coast (Marine Science and Fisheries Center Oman, 2001). In the Gulf of Masirah whales were often observed defecating and surfacing in large schools of shoaling fish after diving for long periods. The 1:1 ratio of males (19) to females (19) observed in the Gulf of Masirah is typical of a feeding ground (Clapham, 1993; Clapham et al., 1995), and the higher percentage of milling whales in the Gulf of Masirah (23\%) vs. Dhofar (6\%), may be a reflection of

Table 5

Results of Chapman corrected Petersen population estimates and 95\% confidence intervals for 3 data pairings, using tail fluke photographs of quality 3 or 4 only.

\begin{tabular}{|c|c|c|c|c|c|c|c|c|}
\hline Data used for $n(1)$ & Data used for $\mathrm{n}(2)$ & $\mathrm{n}(1)$ & $\mathrm{n}(2)$ & $\mathrm{m}(2)$ & $N$ & $\mathrm{CV}$ & Lower 95\% CL & Upper 95\% CL \\
\hline Gulf of Masirah 2001 & Gulf of Masirah 2002 & 12 & 16 & 3 & 54 & 323 & 36 & 82 \\
\hline All individuals 2000-02 & All individuals 2003-04 & 33 & 16 & 6 & 82 & 398 & 60 & 111 \\
\hline
\end{tabular}


Table 6

Frequencies of five fluke pigmentation classes according to study region. Each individual was assigned tail fluke pigmentation categories between 1 and 5 (following Carlson et al. 1990 and Allen et al. 1994): $1=$ all white; $2=$ some black, but less than 25\%; $3=25-75 \%$ black; $4=$ some white but less than 25\%; $5=$ all black.

\begin{tabular}{|c|c|c|c|c|c|c|c|c|c|c|c|c|}
\hline \multirow[t]{2}{*}{ Study area } & \multicolumn{11}{|c|}{ Fluke pigmentation class (fluke photo quality 3 or higher) } & \multirow[b]{2}{*}{ Mean pigment } \\
\hline & \multicolumn{2}{|c|}{1} & \multicolumn{2}{|c|}{2} & \multicolumn{2}{|c|}{3} & \multicolumn{2}{|c|}{4} & \multicolumn{2}{|c|}{5} & Total & \\
\hline Oman & 8 & $25.0 \%$ & 11 & $34.4 \%$ & 8 & $25.0 \%$ & 8 & $12.5 \%$ & 1 & $3.1 \%$ & 32 & 2.34 \\
\hline Antongil Bay & 169 & $47.3 \%$ & 78 & $21.8 \%$ & 43 & $12.0 \%$ & 1 & $7.0 \%$ & 42 & $11.8 \%$ & 357 & 2.14 \\
\hline Mayotte/Geyser & 12 & $46.2 \%$ & 8 & $30.8 \%$ & 4 & $15.4 \%$ & 6 & $3.8 \%$ & 1 & $3.8 \%$ & 26 & 1.88 \\
\hline
\end{tabular}

undetected feeding and/or a satiated, well-fed state (Lockyer, 1981).

It is highly probable that more active and regular feeding takes place outside of our survey periods, particularly between May and September, during peak upwelling associated with the seasonal southwest monsoon. Unfortunately, the monsoon also generates large swell and dense coastal fog, making both boat and shore-based observations difficult. Further research is required to better understand the availability and abundance of possible prey species in the region.

Mikhalev (1997) noted that humpback whales taken in the Eastern Arabian Sea had been feeding predominantly on Euphausiids of an unknown species, while humpbacks taken off the coast of Oman had been feeding exclusively on small shoaling fish (horse mackerels - Carangideae, mackerel, Scomber sp., sardines, Sardinella sp.). It is also interesting to note that stomatopods (Squilla sp.) were found in the stomachs of several Bryde's whale specimens taken in the Soviet catch (Mikhalev, 2000). Stomatopods were also recovered from the stomach of a humpback calf found off the coast of South Africa (Findlay and Best, 1995) and, although no feeding was observed some humpbacks were sighted amid stomatopod swarms during the 2003 Dhofar survey.

\section{Abundance}

Mark-recapture abundance estimates were similar regardless of the method used to separate photographs into different data pairings. However, the application of Petersen estimates to this data set, which represents both a very small sample and a population about which very little is known, may violate at least two of the six key assumptions made in capturerecapture analysis (Seber, 1982). The first assumption that may be violated is that the population is closed. There are no data on recruitment or mortality for Oman humpback whales, and only limited data on the immigration or emigration into or from the survey area. It is possible that we have accessed only a sub-section of a larger Arabian Sea population with a range extending into neighbouring regions in Arabia, East Africa and the Indian sub-continent, and that the markcapture estimates represent only the individuals in the Arabian population that utilise the study.

The second assumption that our study may violate, is that all animals in the population have an equal chance of being captured on the first occasion. Heterogeneity in capture probability is a recognised source of potential bias in most mark-recapture studies (see Hammond, 1990). Whales were more approachable and resultant photographs of higher quality during the Autumn Gulf of Masirah surveys, when $82 \%$ of sightings resulted in a tail fluke photograph of quality 2 or higher. Conversely during the February/March Dhofar surveys, only $44 \%$ of sightings yielded usable tail fluke photographs. This disparity is most likely linked to seasonal behavioural differences. In Dhofar, all but one of the identified whales were determined to be males (either genetically or behaviourally) and certain individuals appear to demonstrate a strong fidelity to specific sites. One individual has been observed (and confirmed to be singing) in the Hallaniyat Islands or Hasik in four successive years. Although six males identified in Dhofar were also observed in the Gulf of Masirah, only one of the 19 known females observed in the Gulf of Masirah has been observed in Dhofar.

High site fidelity of particular males in the Dhofar region may have biased the sample by violating random sampling assumptions. If the Dhofar region contains sites that are preferred by singing males, and surveys are biased toward these sites, our sampling of this region would have been nonrandom. On the other hand, this violation would not account for the high proportion of re-sights (and correlating low population estimate) obtained by using all Gulf of Masirah 'captures' as $n_{1}$ and all Dhofar 'captures' as $n_{2}$

The three chosen data parings are subject to potential bias form these violated assumptions in the following manner. The first (whales photographed in the Gulf of Masirah in 2001 as $n_{1}$ and those photographed in the Gulf of Masriah in 2002 as $n_{2}$ ) may be the most robust, as it represents animals photographed in consecutive years, and a ratio of males to females nearing parity. However, sample sizes in this data pairing are very low. The second data paring (all animals photographed in 2001-02 as $n_{1}$ and all photographed in 2003-04 as $n_{2}$ ) is likely to have a negative bias, due to male heterogeneity (the higher likelihood that males would be sampled in Dhofar). The data pairing is also subject to a potential positive bias, as the combining of years violates the assumption of a closed population and introduces the possibility that new unmarked individuals entered the population between years. The third pairing (all individuals photographed in the Gulf of Masirah between October 2000 and November 2004 as $n_{1}$ and all individuals photographed in Dhofar between January 2000 and March 2004 as $n_{2}$ ) is also subject to both the negative bias of male heterogeneity and the positive bias of the time span/open population.

Despite the possible biases, the high proportion of resightings over this four year period suggests that a number of individuals remain in Omani waters year-round and that at least the Omani component of the Arabian Sea population is small, with numbers in the low hundreds or fewer. Genetic samples collected from Oman, revealed a low haplotype diversity, which could represent a small population or one that has gone through a recent bottleneck (perhaps even as recent as the depletion from Soviet whaling) (Rosenbaum et al., 2009; Pomilla et al., in prep).

Mikhalev (1997) reported 62 whales taken off the coast of Oman (30 from the Halaniyat Islands and 32 from near 
Masirah Island), while a further 20 were observed but not taken. Mikhalev also reported 164 whales taken off the coasts of Pakistan and a further 12 off India, while 14 were observed but not taken off Pakistan. Scientists aboard the 1966 Soviet Fleet estimated that approximately $60 \%$ of the entire Arabian Sea population was taken, although they provide no detail on effort or the methods used to reach this assumption (Mikhalev, 1997).

\section{Stock identity}

The lack of matches found between the Oman, Madagascar, Comoros and Zanzibar catalogues, as well as the significant differences in frequency of fluke pigmentation categories between these populations, support the hypothesis that humpback whales in Oman comprise a separate stock from their Southern Indian Ocean counterparts.

Sexing data were not available for all whales included in photo matching or fluke pigmentation analyses. Previous studies have shown significant sex-related differences in fluke pigmentation. Analysis of whales in the Gulf of Maine and the Dominican Republic showed higher proportions of dark-fluked females and light-fluked males (Allen et al., 1994). Bias toward one sex in a sampling region may also bias the results of fluke pigmentation analysis. It is possible that controlling for sex would yield either more or less significant differences between populations.

Evidence from Soviet catch data and seasonal behaviour and distribution, suggest that at least a significant portion of the humpback whales observed off the coast of Oman adhere to a breeding cycle asynchronous to that of their Southern Hemisphere counterparts. However this does not preclude the possibility that some individuals are engaged in local migrations or exchange across the equator.

While the lack of photographic matches between Oman and Zanzibar, Madagascar or Mayotte and the significant differences in distribution of fluke types both support the hypothesis of a discrete Northern Hemisphere/Arabian Sea population, the existence of several shared haplotypes between Oman and other southern Indian Ocean study areas (Rosenbaum et al., 2009) indicates some genetic exchange may occur or could have occurred in the past.

A more recent and comprehensive genetic mtDNA analysis shows significant population differentiation between Oman and other populations in the western Indian Ocean, as well as the lowest comparative effective migration rates with other sampled populations (Rosenbaum et al., 2009). In fact, the $F_{s t}$ values between Oman and other populations in the southwestern Indian Ocean (Breeding Stock C) and other sampled populations in that study are among the highest recorded for population differentiation values for any humpback worldwide (Rosenbaum et al., 2009). These population level results provide unequivocal evidence for significant differentiation, unique population identity, and high restricted gene flow for the whales of Oman. Further analysis using nuclear markers and an expanded sample size is forthcoming (Pomilla et al., in prep).

Although shared haplotypes may indicate recent or ongoing maternal gene flow between populations, shared maternal lineages do not necessarily establish a recent migratory connection as they can represent ancestral polymorphisms. Shared lineages occur between Southern and Northern Pacific populations of humpback whales in other ocean basins, such as the Eastern Pacific (Caballero et al., 2001). However, exchange between the hemispheres, if it is ongoing, is thought to be limited to overlap of populations on low-latitude breeding grounds off the west coast of Central and South America (Caballero et al., 2001). It is possible that a similar situation exists in the Indian Ocean. Individuals from Oman may come into contact with whales observed off the coast of East Africa (e.g. Kenya, Tanzania and Zanzibar), or the coasts of India, Sri Lanka and the Maldives. Although some anecdotal evidence exists for an 'aseasonal' distribution of whales in these regions (e.g. between the months of October and January) (Weru and Salm, pers. comm. cited in Rosenbaum (2002a)), the majority of reported sightings at these latitudes have been of mothers and calves in the months of August and September (Anderson, 2005; Weru, 2001; PB, unpublished data) indicative of a Southern Hemisphere breeding cycle.

\section{Entanglement histories and scarring}

Analysis of suitable caudal peduncle photographs for evidence of entanglement scarring indicated that between $30 \%$ and $40 \%$ of sampled whales had been entangled. This rate is lower than the $65 \%$ estimated for the Gulf of Maine (Robbins and Mattila, 2000), and lower than the 57\% estimated, for North Atlantic right whales (Kraus, 1990). The Oman estimate is likely to be conservative, as some entanglements may have involved body parts other than the caudal penduncle and some entanglement scarring may have healed or been masked by other types of scars over time. Although documented humpback whale mortalities from entanglement in Oman are low, when viewed in relation to the low population estimates for humpback whales off the coast of Oman, this entanglement rate may represent a significant threat, a concern shared with other small or isolated populations (Clapham et al., 1999b; D'Agrosa et al., 2000; Kraus, 1990).

\section{Conclusions and recommendations}

Presented with the evidence summarised in this paper, as well as the results of genetic analysis of samples from Oman (Pomilla and Rosenbaum, 2006), the IWC's workshop on the Comprehensive Assessment of Southern Hemisphere humpback whales designated the Arabian Sea humpback whale population a separate breeding stock, Population X, isolated from other Indian Ocean stocks and resident in the Arabian Sea year round (IWC, 2011). Given the stock's isolated status and low abundance estimate, the workshop 'strongly recommended that further research be undertaken that will aid in protection of this stock'. Scarring analyses indicate that entanglement in fishing gear may present a significant threat to the population, and the rapid development of Oman's economy and infrastructure, much of which is focused on coastal and marine areas, may have significant impacts on the identified feeding and breeding habitats of this population. The data presented here together with evidence of mounting developments and threats to coastal habitats in Oman also led to the designation of the Arabian Sea sub-population of humpback whales as Endangered in the IUCN Red List (Minton et al., 2008). These potential threats require immediate emphasis to be placed on research, management and conservation efforts.

The workshop also recommended that studies be conducted in unsampled areas between Oman and other study areas in East Africa and Western Australia where humpback whales have been incidentally observed (e.g. Braulik et al., 2010; Brown, 1957; Lal Mohan, 1992; Mikhalev, 1997; Reeves et al., 1991; Sathasivam, 2000; Slijper et al., 1964; Weru, 2001; Whitehead, 1985). It recommended further genetic sampling and analysis to more conclusively determine the degree of differentiation for 
humpback whales of Region $X$ and the timing of its separation from other humpback whale populations. Finally, given the seasonal limitations in survey effort and an unresolved degree of movement and connectivity with other concentrations of humpback whales in the Indian Ocean, the Workshop also suggested that satellite telemetry studies be initiated. In 2011, the IWC Scientific Committee acknowledged that sufficient data exist on Arabian Sea humpback whales and possible anthropogenic threats to begin the process for the development of a Conservation Management Plan through which earlier recommendations for the study and conservation of the population may be most effectively achieved.

In addition to the conservation value of the recommended research, the study of non-migratory populations may shed light on the forces driving other populations to migrate (Clapham, 2000). Focal work on this population could elucidate other aspects of humpback whale behaviour and ecology. For instance there is still significant debate surrounding the function of humpback whale song. Other studies are generally conducted on densely populated breeding grounds where individual singers are difficult to isolate and monitor over time (Cherchio, 2003). Although whales in Oman are few, they are readily identifiable and show a high degree of site fidelity and are may be good candidates for behavioral work.

\section{ACKNOWLEDGEMENTS}

The Madagascar and Mayotte catalogues were made available courtesy of the Cetacean Conservation and Research Program (a joint program of The Wildlife Conservation Society and the American Museum of Natural History). Tissue samples were analysed at the Sackler Institute for Comparative Genomics, American Natural History Museum. Logistic support and vital permissions to conduct research in the Sultanate of Oman were provided by the Ministry of Regional Municipalities, Environment and Water Resources, the Oman Natural History Museum and the Ministry of Agriculture and Fisheries. A number of people assisted with fieldwork, data entry and analysis, including Phil Hammond, Vic Cockcroft, Anna HywelDavies, Fergus Kennedy, Andy Willson, Cristina Pomilla, Matt Leslie, Simon Wilson, Kris Vallancey, Simon and Virginie Collins, Richard and Edward Willing, David Ames, Anna McKibbon, Mandy Senior, Brenda Rone, Louisa Ponnampalam, Oli Taylor and Natalie Little. The fieldwork completed in Oman would not have been possible without the significant financial and logistic support provided by The Ford Environmental Grants, The UK Foreign and Commonwealth Office, Shell Marketing Oman, Petroleum Development Oman, Veritas Geophysical, The Peter Scott Trust for Education and Research in Conservation, Emirates Airlines, Salalah Port Services, DHL Worldwide Express, Truck Oman, Oman Air, The Wildlife Conservation Society, Muscat Pharmacy, KPMG, Han-Padron and Associates, and the Marina Bandar al Rowdah. The authors would also like to thank two anonymous reviewers, whose comments significantly improved this manuscript.

\section{REFERENCES}

Acevedo-Gutiérrez, A. and Smultea, M.A. 1995. First records of humpback whales including calves at Golfo Dulce and Isla del Coco, Costa Rica, suggesting geographical overlap of northern and southern hemisphere populations. Mar. Mammal Sci. 11(4): 554-60.
Ahmed, M.F. and Rizvi, S.N.H. 1985. Stranding of a humpback whale (Megaptera novaeangliae, Borowski 1781) on the Sind coast. Rec. Zool. Surv. Pak. 10(1, 2): 111-12.

Allen, J.M., Rosenbaum, H.C., Katona, S.K., Clapham, P.J. and Mattila, D.K. 1994. Regional and sexual differences in fluke pigmentation of humpback whales (Megaptera novaeangliae) from the North Atlantic Ocean. Can. J. Zool. 72(2): 274-79.

Alling, G., Gordon, J., Rotton, N. and Whitehead, H. 1982. WWFNetherlands Indian Ocean sperm whale study, 1981-1982 interim report. Paper SC/34/Sp9 presented to the IWC Scientific Committee, June 1982 (unpublished). 46pp. [Paper available from the Office of this Journal].

Amos, W. and Hoelzel, A.R. 1991. Long-term preservation of whale skin for DNA analysis. Rep. int. Whal. Commn (special issue) 13: 99-103.

Amos, W., Whitehead, H., Ferrari, M.J., Glockner-Ferrari, D.A., Payne, R. and Gordon, J. 1992. Restrictable DNA from sloughed cetacean skin; its potential for use in population analysis. Mar. Mammal Sci. 8(3): 275-83.

Anderson, R.C. 2005. Observations of cetaceans in the Maldives, 19902002. J. Cetacean Res. Manage. 7(2): 119-36.

Baker, C.S. and Herman, L.M. 1984. Aggressive behavior between humpback whales (Megaptera novaeangliae) wintering in Hawaiian waters. Can. J. Zool. 62: 1922-37.

Baker, C.S. and Medrano-González, L. 2001. World-wide distribution and diversity of humpback whale mitochondrial DNA lineages. pp.84-99. In: Pfeiffer, C.J. (eds). Molecular and Cell Biology of Marine Mammals. Krieger Publishing Co., Melbourne, FL 2002.

Baker, C.S., Palumbi, S.R., Lambertsen, R.H., Weinrich, M.T., Calambokidis, J. and O'Brien, S.J. 1990. Influence of seasonal migration on geographic distribution of mitochondrial DNA haplotypes in humpback whales. Nature 344(6263): 238-40.

Baker, C.S., Flórez-González, L., Abernethy, B., Rosenbaum, H.C., Slade, R.W., Capella, J. and Bannister, J.L. 1998. Mitochondrial DNA variation and maternal gene flow among humpback whales of the Southern Hemisphere. Mar. Mammal Sci. 14(4): 721-37.

Baldwin, R. 1997. Records of Wildlife and Observed Operational Impacts on Wildlife. Seismic Survey, Block 22, Oman. Environmental Observation Report 1. 1-76, Oman. [Unpublished report for Triton Oman Inc.]

Baldwin, R. 2000. Oman's humpback whales (Megaptera novaeangliae). The Journal of Oman Studies 11: 11-18.

Ballance, L.T. and Pitman, R.L. 1998. Cetaceans of the western Tropical Indian Ocean: distribution, relative abundance, and comparisons with cetacean communities of two other tropical ecosystems. Mar. Mammal Sci. 14(3): 429-59.

Blackmer, A.L., Anderson, S.K. and Weinrich, M.T. 2000. Temporal variability in features used to photo-identify humpback whales (Megaptera novaeangliae). Mar. Mammal Sci. 16(2): 338-54.

Braulik, G.T., Ranjbar, S., Owfi, F., Aminrad, T., Dakhteh, S.M.H., Kamrani, E. and Mohsenizadeh, F. 2010. Marine mammal records from Iran. J. Cetacean Res. Manage. 11(1): 49-64.

Breiwick, J.M. 1983. Methods and data required for whale stock assessments. Rep. int. Whal. Commn (special issue) 5: 19-22.

Brock, J.C. and McClain, C.R. 1992. Interannual variability in phytoplankton blooms observed in the northwestern Arabian Sea during the southwest monsoon. J. Geophys. Res. 97(CI): 733-50.

Brock, J.C., Sathyendranath, S. and Platt, T. 1998. Biohydro-optical classification of the northwestern Indian Ocean. Mar. Ecol. Prog. Ser. 165: 1-15.

Brown, M. and Corkeron, P. 1995. Pod characteristics of migrating humpback whales (Megaptera novaeangliae) off the east Australian coast. Behaviour 132: 163-79.

Brown, S.G. 1957. Whales observed in the Indian Ocean. Notes on their distribution. Mar. Obs. 27(177): 157-65.

Caballero, S., Hamilton, H., Jaramillo, H., Capella, J., Flórez-González, L., Olavarría, C., Rosenbaum, H.C., Guhl, F. and Baker, C.S. 2001. Genetic characterisation of the Colombian Pacific Coast humpback whale population using RAPD and mitochondrial DNA sequences. Mem. Queensl. Mus. 47: 459-64.

Carlson, C.A., Mayo, C.A. and Whitehead, H. 1990. Changes in the ventral fluke pattern of the humpback whale (Megaptera novaeangliae), and its effects on matching; evaluation of its significance to photo-identification research. Rep. int. Whal. Commn (special issue) 12: 105-11.

Chapman, D.G. 1951. Some properties of the hypergeometric distribution with applications to zoological censuses. Univ. Calif. Publ. Statist. 1: 131-60.

Cherchio, S. 2003. Paternity, polygyny and alternative mating tactics in humpback whales (Megaptera novaeangliae), University of Michigan, Michigan. 165pp.

Chittleborough, R.G. 1965. Dynamics of two populations of the humpback whale, Megaptera novaeangliae (Borowski). Aust. J. Mar. Freshwater Res. 16(1): 33-128.

Clapham, P.J. 1993. Social organisation of humpback whales on a North Atlantic feeding ground. Symp. Zool. Soc., Lond. 66: 131-45. 
Clapham, P.J. and Mead, J.G. 1999. Megaptera novaeangliae. Mamm. Species 604: 1-9.

Clapham, P.J., Palsbøll, P.J., Mattila, D.K. and Vasquez, O. 1992. Composition and dynamics of humpback whale competitive groups in the West-Indies. Behaviour 122(Part 3-4): 182-94.

Clapham, P.J. 2000. The humpback whale: seasonal feeding and breeding in a baleen whale. pp.173-96. In: Mann, J., Connor, R.C., Tyack, P.L. and Whitehead, H. (eds). Cetacean Societies. Field Studies of Dolphins and Whales. The University of Chicago Press, Chicago. 433pp.

Clapham, P.J., Bérubé, M. and Mattila, D.K. 1995. Sex ratio of the Gulf of Maine humpback whale population. Mar. Mammal Sci. 11(2): 227-31.

Clapham, P.J., Wetmore, S.E., Smith, T.D. and Mead, J.G. 1999a. Length at birth and at independence in humpback whales. J. Cetacean Res. Manage. 1(2): 141-46.

Clapham, P.J., Young, S.B. and Brownell, R.L., Jr. 1999b. Baleen whales: conservation issues and the status of the most endangered populations. Mammal Rev. 29(1): 35-60.

Corkeron, P.J., Minton, G., Collins, T., Findlay, K., Wilson, A. and Baldwin, R. 2011. Spatial models of sparse data to inform cetacean conservation planning: an example from Oman. Endangered Species Research 15: 39-52.

Craig, A.S., Herman, L.M., Gabriele, C.M. and Pack, A.A. 2003. Migratory timing of humpback whales (Megaptera novaeangliae) in the Central North Pacific varies with age, sex, and reproductive status. Behaviour 140: 981-1001.

D’Agrosa, C., Lennert-Cody, C.E. and Vidal, O. 2000. Vaquita by-catch in Mexico's artisanal gillnet fisheries: driving a small population to extinction. Conserv. Biol. 14: 1110-19.

Dawbin, W.H. 1966. The seasonal migratory cycle of humpback whales. pp.145-70. In: Norris, K.S. (eds). Whales, Dolphins, and Porpoises. University of California Press, Berkeley and Los Angeles. xv+789pp.

de Silva, P.H.D.H. 1987. Cetaceans (whales, dolphins and porpoises) recorded off Sri Lanka, India, from the Arabian Sea and Gulf, Gulf of Aden and from the Red Sea. J. Bombay Nat. Hist. Soc. 84(3): 50525 .

Ersts, P. and Rosenbaum, H. 2002. Report of humpback whale sightings around Mayotte and on the Geyser/Zelee Complex, 27 August to 25 September 2002. American Natural History Museum: 1-18.

Ersts, P.J. and Rosenbaum, H.C. 2003. Habitat preference reflects social organization of humpback whales (Megaptera novaeangliae) on a wintering ground. J. Zool., London. 260: 337-45.

Eyre, E.J. 1995. Observations of cetaceans in the Indian Ocean Whale Sanctuary, May-July 1993. Rep. int. Whal. Commn 45: 419-26.

Findlay, K.P. and Best, P.B. 1995. Summer incidence of humpback whales on the west coast of South Africa. S. Afr. J. Mar. Sci 15: 279-82.

Findlay, K., Meÿer, M., Elwen, S., Kotze, D., Johnson, R., Truter, P., Uamusse, C., Sitoe, S., Wilke, C., Kerwath, S., Swanson, S., Staverees, L. and van der Westhuizen, J. 2011. Distribution and abundance of humpback whales, Megaptera novaeangliae, off the coast of Mozambique, 2003. J. Cetacean Res. Manage. (special issue 3): 163-174

Flórez-González, L., Capelia, J., Haase, B., Bravo, G.A., Felix, F. and Gerrodette, T. 1998. Changes in winter destinations and the northernmost record of southeastern Pacific humpback whales. Mar. Mammal Sci. 14(1): 189-96.

Friday, N., Smith, T., Stevick, P. and Allen, J. 2000. Measurement of photographic quality and whale distinctiveness for the photographic identification of humpback whales. Mar. Mammal Sci. 16(2): 355-74.

Garrigue, C., Greaves, J. and Chambellant, M. 2001. Characteristics of the New Caledonian humpback whale population. Mem. Queensl. Mus. 47(2): 539-46.

Hammond, P.S. 1990. Heterogeneity in the Gulf of Maine? Estimating humpback whale population size when capture probabilities are not equal. Rep. int. Whal. Commn (special issue) 12: 135-39.

Hazevoet, C.J. and Wenzel, F.W. 2000. Whales and dolphins (Mammalia, Cetacea) of the Cape Verde Islands, with special reference to the humpback whale (Megaptera novaeangliae) (Borowski, 1781). Contrib. Zool. 69(3): 197-211.

International Whaling Commission. 2001. Report of the workshop on status and trends of western North Atlantic right whales. J. Cetacean Res. Manage. (special issue) 2:61-87.

International Whaling Commission. 2011. Report of the Workshop on the Comprehensive Assessment of Southern Hemisphere humpback whales, 4-7 April 2006, Hobart, Tasmania. J. Cetacean Res. Manage. (special issue 3): $1-50$.

Katona, S.K. and Whitehead, H.P. 1981. Identifying humpback whales using their natural markings. Polar Rec. 20: 439-44.

Kraus, S.D. 1990. Rates and potential causes of mortality in North Atlantic right whales (Eubalaena glacialis). Mar. Mammal Sci. 6(4): 27891.
Lal Mohan, R.S. 1992. Observations on the whales Balaenoptera edeni, B. musculus and Megaptera novaeangliae washed ashore along the Indian coast with a note on their osteology. J. Mar. Biol. Assoc. India 34(1 and 2): 253-55.

Lambertsen, R.H., Baker, C.S., Weinrich, M. and Modi, W.S. 1994. An improved whale biopsy system designed for multidisciplinary research. pp.219-44. In: Fossi, M.C. and Leonzio, C. (eds). Nondestructive Biomarkers in Vertebrates. Lewis Publishers, Boca Raton, Florida. Paper SC/58/For Info 31 presented to the IWC Scientific Committee, May 2006 , St. Kitts and Nevis, West Indies.

Leaper, R., Cooke, J., Trathan, P., Reid, K. and Rowntree, V. 2006. Global climate change drives southern right whales (Eubalaena australis) population dynamics. Biology Letters 2: 289-92.

Lockyer, C. 1981. Growth and energy budgets of large baleen whales from the Southern Hemisphere. FAO Fisheries Series No. 5 (Mammals in the Sea) 3: 379-487

Lockyer, C. 1984. Review of baleen whale (Mysticeti) reproduction and implications for management. Rep. int. Whal. Commn (special issue) 6: $27-50$.

Marine Science and Fisheries Center Oman. 2001. Ecological studies in the coastal waters of Oman and selecting of sites for aquaculture: progress report no. 2. Ministry of Agriculture and Fisheries, Directorate General of Fisheries Resources, Marine Science and Fisheries Center, Marine Ecology Laboratory. 81pp.

Mathew, A.P. 1948. Stranding of a whale (Megaptera nodosa) on the Travancore coast in 1943. J. Bombay Nat. Hist. Soc. 47: 732-33.

Mattila, D.K., Clapham, P.J., Katona, S.K. and Stone, G.S. 1989. Population composition of humpback whales, Megaptera novaeangliae, on Silver Bank, 1984. Can. J. Zool. 67: 281-85. [Abstract also in French].

Mattila, D.K., Clapham, P.J., Vásquez, O. and Bowman, R.S. 1994 Occurrence, population composition, and habitat use of humpback whales in Samana Bay, Dominican Republic. Can. J. Zool. 72(11): 1898 907.

Medrano-Gonzalez, L., Baker, C.S., Robles-Saavedra, J., Murell, M.J., Vázquez-Cuevas, B.C., Congdon, J.M., Straley, J., Calambokidis, J., Urban-Ramirez, J., Florez-Gonzales, L., Olavarria, C., Aguayo-Lobo, A., Nolasco-Soto, J., Juarez-Salas, R.A. and Villavicencio-Llamosas, K. 2001. Trans-oceanic population genetic structure of humpback whales in the north and south Pacific. Mem. Queensl. Mus. 47(2): 465-79.

Mikhalev, Y.A. 1997. Humpback whales, Megaptera novaeangliae in the Arabian Sea. Marine Ecology. Progress Series 149: 13-21.

Mikhalev, Y.A. 2000. Whaling in the Arabian Sea by the whaling fleets Slava and Sovetskaya Ukraina. pp.141-81. In: Yablokov, A.V., Zemsky, V.A. and Tormosov, D.D. (eds). Soviet Whaling Data (1949-1979). Centre for Russian Environmental Policy, Moscow. 408pp.

Minton, G., Collins, T., Findlay, K. and Baldwin, R. 2010. Cetacean distribution in the coastal waters of the Sultanate of Oman. J. Cetacean Res. Manage. 11(3): 301-14.

Minton, G., Collins, T., Pomilla, C., Findlay, K., Rosenbaum, H., Baldwin, R. and Brownell, R.L., Jr. 2008. Megaptera novaeangliae (Arabian Sea sub-population). IUCN Red List of Threatened Species. [http://www.iucnredlist.org/details/132835]

Pack, A.A., Herman, L.M., Craig, A.S., Spitz, S.S. and Deakos, M.H. 2002. Penis extrusions by humpback whales (Megaptera novaeangliea). Aquat. Mamm. 28(2): 131-46. Abstract in IWC Library.

Palsbøll, P.J., Vader, A., Bakke, I. and El-Gewely, M.R. 1992. Determination of gender in cetaceans by the polymerase chain reaction. Can. J. Zool. 70: $2166-70$

Papastavrou, V. and Van Waerebeek, K. 1997. A note on the occurrence of humpback whales (Megaptera novaeangliae) in tropical and subtropical areas: the upwelling link. Rep. int. Whal. Commn 47: 945-47.

Payne, R. and McVay, S. 1971. Songs of humpback whales. Science 173: 585-97.

Pomilla, C. and Rosenbaum, H.C. 2006. Estimates of relatedness in groups of humpback whales (Megaptera novaeangliae) on two wintering grounds of the Southern Hemisphere. Mol. Ecol. 15(9): 2541-55.

Reeves, R.R., Leatherwood, S. and Papastavrou, V. 1991. Possible stock affinities of humpback whales in the northern Indian Ocean. pp.259-70. In: Leatherwood, S. and Donovan, G. (eds). Cetaceans and Cetacean Research in the Indian Ocean Sanctuary: Marine mammal technical report number 3. UNEP, Nairobi, Kenya. United Nations Environment Programme, Marine Mammal Technical Report Number

Robbins, J. and Mattila, D.K. 2000. Gulf of Maine humpback whale entanglement scar monitoring results 1997-1999, Center for Coastal Studies, Provincetown, MA. 24pp.

Rosenbaum, H.C., Collins, T., Minton, G., Baldwin, R., Glaberman, S., Findlay, K.P. and Best, P. 2002a. Preliminary analysis of mtDNA variation among humpback whales off the coast of Oman and their relationship to whales from wintering grounds in the southwestern Indian 
Ocean. Paper SC/54/H4 presented to the IWC Scientific Committee, April 2002, Shimonoseki, Japan (unpublished). 10pp. [Paper available from the Office of this Journal]

Rosenbaum, H.C., Ersts, P.J., Razafindrakoto, Y., Sounguet, G., Pomilla C., Ngouessono, S., Rasoamampianina, V. and White, L. 2002b. Population characteristics, distribution, and relative abundance of humpback whales off the coasts of Madagascar and Gabon: an update on recent and planned research. Paper SC/54/H20 presented to the IWC Scientific Committee, April 2002, Shimonoseki, Japan. 13pp. [Paper available from the Office of this Journal].

Rosenbaum, H.C., Pomilla, C., Mendez, M.C., Leslie, M.C., Best, P.B., Findlay, K.P., Minton, G., Ersts, P.J., Collins, T., Engel, M.H., Bonatto, S., Kotze, D.P.G.H., Meyer, M., Barendse, J., Thornton, M., Razafindrakoto, Y., Ngouessono, S., Vely, M. and Kiszka, J. 2009. Population structure of humpback whales from their breeding grounds in the South Atlantic and Indian Oceans. PLOS ONE 4(10): 11pp. [e7318. doi: 10.1371/journal.pone.0007318]

Salm, R.V., Jensen, R.A.C. and Papastavrou, V.A. 1993. Marine Fauna of Oman: cetaceans, turtles, seabirds and shallow water corals. A Marine Conservation and Development Report. IUCN, Gland, Switzerland. $66 \mathrm{pp}$

Sathasivam, K. 2000. A catalogue of Indian marine mammal records. Blackbuck 16(2 and 3): 23-74.
Seber, G.A.F. 1982. The Estimation of Animal Abundance and Related Parameters. 2nd ed. Charles Griffin and Company Ltd., London. ixvii+654pp.

Slijper, E.J., van Utrecht, W.L. and Naaktgeboren, C. 1964. Remarks on the distribution and migration of whales, based on observations from Netherlands ships. Bijdr. Dierkd. 34: 3-93.

Smultea, M.A. 1994. Segregation by humpback whale (Megaptera novaeangliae) cows with a calf in coastal habitat near the island of Hawaii. Can. J. Zool. 72(5): 805-11.

Stone, G.S., Flórez-González, L. and Katona, S. 1990. Whale migration record. Nature 346: 705-06.

Tyack, P. 1981. Interactions between singing Hawaiian humpback whales and conspecifics nearby. Behav. Ecol. Sociobiol. 8: 105-16.

Weru, S. 2001. Rapid baseline survey of large marine animals, with special emphasis on humpback whales, in Kenya. KWS Technical Series. [Available from:werus@africaonline.co.ke].

Whitehead, H. 1985. Humpback whale songs from the North Indian Ocean. Invest. Cetacea 17: 157-62.

Winn, H.E., Thompson, T.J., Cummings, W.C., Hain, J., Hundnall, J., Hays, H. and Steiner, W.W. 1981. Songs of the humpback whale - population comparisons. Behav. Ecol. Sociobiol. 8: 41-46.

Wray, P. and Martin, K.R. 1983. Historical whaling records from the western Indian Ocean. Rep. int. Whal. Commn (special issue)(5): 213-41. 